\title{
Seasonal changes and content of sodium in main organs of European plum trees (Prunus domestica L.), fruit size and yield as affected by rootstocks on acidic soil
}

\section{Mudanças sazonais no teor de sódio dos órgãos, tamanho do fruto e produção da ameixeira européia (Prunus domestica L.) em função de porta-enxertos em solo ácido}

\author{
Nebojša Milošević' $;$ Tomo Milošević ${ }^{*}$
}

\begin{abstract}
In the present study, the seasonal changes of $\mathrm{Na}$ content of shoots, flower buds and flowers, and fruit weight and yield of two European plum cultivars ('Cacanska Lepotica' and 'Cacanska Najbolja') budded on Myrobalan (Prunus cerasifera Ehrh.) and Stanley rootstocks were analyzed after 6-8 years of planting on acidic sandy-loam soil. The Na content of the shoots and flower buds of each rootstock/ cultivar combination varied during season, and the highest content in above organs was observed in May and August, respectively. The effect of rootstocks on the examined parameters was variable due to the strong rootstock/cultivar/year interaction observed. The shoots and flower buds of cultivars budded on Stanley and Myrobalan rootstocks gave the highest and lowest Na content, respectively, whereas the highest $\mathrm{Na}$ content in flowers registered in 'Cacanska Lepotica' on Myrobalan. The content of $\mathrm{Na}$ in the plum organs suggests the following trends: 1-year old shoots $>2$-year-old shoots $>$ flower buds $>$ flowers. There were no statistically significant correlations among plum organs with respect to Na content. The Principal Component Analysis showed that Stanley rootstock had a higher $\mathrm{Na}$ accumulation and distribution capacity than Myrobalan rootstock in plum trees. Finally, content of $\mathrm{Na}$ in the main organs of plum trees and acidic soil have not a negative effect on fruit weight and yield of plum cultivars, since these properties were respectable.
\end{abstract}

Key words: Acidic soil, fruit weight and yield, plum trees, shoots, sodium accumulation

\section{Resumo}

\begin{abstract}
Neste estudo, foram analisadas as mudanças sazonais do teor de $\mathrm{Na}$ nos ramos, botões florais e flores, bem como no peso dos frutos e na produtividade de duas cultivares de ameixeiras européias ('Cacanska lepotica' e 'Cacanska najbolja') enxertadas sobre os porta-enxertos Myrobalan (Prunus cerasifera Ehch.) e Stanley, aos 6-8 anos após o plantio em solo ácido areno-argiloso. O conteúdo de Na nos ramos e nos botões florais para cada combinação de copa/porta-enxerto teve a variação durante a temporada e o maior teor foi constatado em maio e agôsto, respectivamente. A influência do porta-enxerto sobre os parâmetros estudados foi variável devido à forte interação copa/porta-enxerto/ano. Os ramos e botãos florais das plantas enxertadas sobre os porta-enxerto Stanley e Myrobalan, tiveram o maior e o menor teor de $\mathrm{Na}$, respectivamente; enquanto o maior teor de $\mathrm{Na}$ nas flores foi registrado na 'Cacanska lepotica' sobre o porta-enxerto Myrobalan. O conteúdo de Na nos órgãos de ameixa teve a seguinte
\end{abstract}

1 Ph.D. student, Department of Pomology and Fruit Breeding, Fruit Research Institute, Kralja Petra I/9, 32000 Cacak, Serbia. E-mail: mnebojsa@tfc.kg.ac.rs

2 Prof. Department of Fruit Growing and Viticulture, Faculty of Agronomy, Cara Dusana 34, 32000 Cacak, Serbia. E-mail: tomom@tfc.kg.ac.rs

Author for corespondence 
evolução: ramos de 1 ano $>$ ramos de 2 anos $>$ botões florai $>$ flores. Não houve correlação significativa entre os órgãos da ameixeira em termos de teor de $\mathrm{Na}$. A Análise de Componentes Principais mostrou que o porta-enxerto Stanley teve uma capacidade maior de armazenamento e distribuição de $\mathrm{Na}$ do que o porta-enxerto Myrobalan nas plantas. $\mathrm{O}$ teor de $\mathrm{Na}$ nos órgãos da ameixeira e o solo ácido não afectaram negativamente o peso dos frutos e a produção das variedades de ameixas, que tiveram resultados positivos.

Palavras-chave: Acidez do solo, qualidade do fruto, ameixa, ramos, acúmulo de $\mathrm{Na}$

\section{Introduction}

Low soil $\mathrm{pH}$ accounts for considerable yield losses of a wide variety of crops all over the world. This problem is more severe in humid and mountain regions, including the Western Serbia (MILOŠEVIĆ; MILOŠEVIĆ, 2010), where it is one of the major limiting factors to fruit crop productivity. This problem can be prevented or mitigated by soil and water management, and crop productivity under acidic soils could be improved using tolerant genotypes (ASHRAF; AHMAD, 2000; HUSSAIN et al., 2003) and/or fruit cultivars grafted on tolerant rootstock (BERNSTEIN; BROWN; HAYWARD, 1956). Acidic soils could inhibit plant growth and reduce plant productivity by water excess, ionic toxicity and nutritional imbalance (VON UEXKÜLL; MUTERT, 1995).

Sodium concentrations in soils vary considerably depending on regional and local hydrological and geological conditions, the time of year, and salt utilization patterns. In regions of heavy rain fall therefore, the drainage water usually contains only a very small concentration of ionic species and there is no significant accumulation of salts in any part of the soil profile. Sodium uptake from the soil is a major cause of salinity toxicity in plants, yet little is known about the mechanisms that underlie $\mathrm{Na}$ influx (CANNEL; KIMEU, 1971; MAATHUIS; SANDERS, 2001). Because of the high solubility of sodium minerals, sodium is ubiquitous in the water environment. As sodium is not strictly an essential element it cannot be expected to have a specific role in the metabolic activities of plants. Where sodium produces significant effects it is often regarded as a conserver of potassium and as being able partly to replace that element in its role. In no instance, however, has it been shown that sodium can wholly replace potassium where the latter is acutely deficient (ANONIMOUS, 2010). Most studies focus on the toxic effect of sodium on fruit crops, as most fruit trees, including plum (Prunus domestica L.), are sensitive to salinity (BERNSTEIN; BROWN; HAYWARD, 1956; HOFFMAN et al., 1989; CATLIN et al., 1993; BOLAT et al., 2006). However, the small number of studies related to sodium uptake by plum trees in acidic soils and their effect on fruit size and yield in modern plum orchards. In Western Serbian conditions, the soils in these plum orchards are poor chemical properties (MILOŠEVIĆ; MILOŠEVIĆ, 2010).

The present study therefore aims to evaluate the seasonal changes of sodium content in 1- and 2-year-old shoots, flower buds and flowers of two European plum cultivars budded on two rootstocks grown on acidic sandy-loam soil in Western Serbia. Also, our wish was to determine the extent to which acidic soil and sodium content in soil and plum organs affect on fruit size and yield of plum in High Density Planting (HDP) system.

\section{Materials and Methods}

\section{Area studied location}

The study was conducted at a plum orchard located at the village of Prislonica, $15 \mathrm{~km}$ northeast of Cacak (435' $\mathrm{N}$; $20^{\circ} 21^{\prime} \mathrm{E}$; $340 \mathrm{~m}$ above sea level), Western Serbia. The plum cultivars 'Cacanska Lepotica' and 'Cacanska Najbolja' were used. The seedlings of Myrobalan (Prunus cerasifera Ehrh.) and Stanley were used as rootstocks. They were planted in spring 2000. The trees were planted in a randomised block design with three replicates at a 4 
$\mathrm{m} \times 2 \mathrm{~m}$ spacing $\left(1,250\right.$ trees $\left.\mathrm{ha}^{-1}\right)$. The surface area of the orchard was 0.50 ha. The trial was conducted during 2006, 2007 and 2008, i.e. at the full bearing stage (6-8 year after planting). The orchard was fertilised with $300 \mathrm{~kg} \mathrm{ha}^{-1}$ of Calcium Ammonium Nitrate (containing $27 \%$ of $\mathrm{N}_{\text {TOT }}$ ) prior to the onset of the vegetative cycle. Standard cultural practices were applied, except irrigation.

\section{Basic climatological parameters}

The climate is maritime temperate or $\mathrm{Cfb}$ (KOTTEK et al., 2006) with moderate to strong winters, and hot and semi to dry summers. The basic climatological parameters for the period of observation and the long-term averages for the region of Cacak and the surrounding areas are given in Table 1. The mean temperature in 2006 was $0.9^{\circ} \mathrm{C}$ lower than the long-term average; it was $0.7^{\circ} \mathrm{C}$ and $1.6^{\circ} \mathrm{C}$ lower than normal in 2007 and 2008 , respectively; normal being a 30 -year average. The total precipitation in 2006 was $75.9 \mathrm{~mm}$ higher than normal; in 2007, it was $139.9 \mathrm{~mm}$ lower than the long-term average, and in 2008, it was $21.2 \mathrm{~mm}$ higher than normal.

Table 1. Monthly air temperatures and precipitation in Cacak in 2006-2008*.

\begin{tabular}{lcccccccc}
\hline \multirow{2}{*}{ Months } & \multicolumn{4}{c}{ Air temperature $\left({ }^{\circ} \mathbf{C}\right)$} & \multicolumn{3}{c}{ Precipitation $^{(\mathbf{m m})}$} \\
\cline { 2 - 8 } & $\mathbf{2 0 0 6}$ & $\mathbf{2 0 0 7}$ & $\mathbf{2 0 0 8}$ & Normal $^{\text {** }}$ & $\mathbf{2 0 0 6}$ & $\mathbf{2 0 0 7}$ & $\mathbf{2 0 0 8}$ & Normal $^{\text {** }}$ \\
\hline January & -4.4 & 0.2 & -3.2 & -0.2 & 55.3 & 0.3 & 101.4 & 30.7 \\
February & -2.7 & -1.7 & 1.2 & 1.9 & 0.8 & 87.6 & 6.1 & 38.9 \\
March & 5.1 & 5.0 & 0.6 & 6.7 & 17.1 & 37.2 & 45.7 & 42.5 \\
April & 12.1 & 13.3 & 10.1 & 11.4 & 85.7 & 25.1 & 23.5 & 51.2 \\
May & 18.1 & 17.1 & 12.9 & 17.4 & 72.9 & 103.1 & 165.3 & 56.4 \\
June & 18.3 & 17.1 & 18.5 & 20.5 & 86.8 & 109.3 & 20.4 & 88.4 \\
July & 21.5 & 18.5 & 22.3 & 22.2 & 43.5 & 72.6 & 15.7 & 52.6 \\
August & 21.6 & 20.2 & 18.2 & 21.9 & 110.5 & 10.9 & 74.3 & 51.6 \\
September & 17.3 & 16.1 & 18.0 & 16.3 & 5.6 & 0.9 & 17.8 & 56.6 \\
October & 10.8 & 14.2 & 10.2 & 11.5 & 18.5 & 2.1 & 47.0 & 57.6 \\
November & 4.1 & 6.4 & 6.0 & 5.43 & 187.4 & 13.7 & 75.0 & 52.8 \\
December & 2.7 & 0.3 & 1.8 & 0.8 & 23.8 & 29.3 & 61.0 & 52.7 \\
Mean or total & 10.4 & 10.6 & 9.7 & 11.3 & 707.9 & 492.1 & 653.2 & 632.0 \\
\hline
\end{tabular}

${ }^{*}$ At a straight-line distance of $15 \mathrm{~km}$ (NE-direction) from the experimental field.

${ }^{* *}$ Normal refers to the long-term average (30-year average, i.e. 1977-2006).

Source: Elaboration of the authors.

Generally, mean temperatures during the calendar year(s) did not deviate from the longterm period, but the values measured were below normal. As for total precipitation, year-to-year variations were most pronounced. The substantial precipitation deficiency observed in the second year of the study, as compared to the long-term period, may have affected the results of this study.

\section{Soil chemical analysis}

The soil chemical analysis was repeated in midNovember 2006, 2007 and 2008 to determine the chemical composition. The samples were taken from three depths: 0-20, 20-40 and 40-60 cm from 20 points per hectare for each depth. The samples were ground and sifted in a $2 \mathrm{~mm}$ mesh. Once homogenized, a $5 \mathrm{~g}$ sub-sample was dried at $105^{\circ} \mathrm{C}$ and ground in a Speck 8000 Mixer/Mill until the 
material passed through a mesh of 100 screens. A Pye glass electrode $\mathrm{pH}$-meter-potentiometer (W.G. Pye, Cambridge) was used to measure $\mathrm{pH}$ in 0.01 $\mathrm{M} \mathrm{KCl}$.

The organic matter content was determined according to the Walkley-Black method in an automatic analyzer (Shimadzu TOC 5000-A), and $\mathrm{N}_{\text {тот }}$ by the Kjeldahl method using sulphuric acid and a metal catalyst. Available $\mathrm{P}_{2} \mathrm{O}$ and $\mathrm{K}_{2} \mathrm{O}$ were determined by extraction with $\mathrm{Al}$ solution (EGNER; RIEHM; DOMINGO, 1960) using spectrophotometry (Hewlett Packard 8452A) with molybdate and flame photometry (Corning 405 ), respectively. The $\mathrm{CaO}, \mathrm{MgO}$ and $\mathrm{Na}_{2} \mathrm{O}$ were determined by atomic absorption spectrophotometry (Pye Unicam SP 191). Electrical conductivity (EC) were determined electrometrically using EC meter (SM 802, Milwaukee) (GHOSH et al., 1983). Values are given as a $\mathrm{dS} \mathrm{m}^{-1}$ at $25^{\circ} \mathrm{C}$.

\section{Plant chemical and pomological analysis}

The identical number (20) of 1-year-old (OS) and 2-year-old shoots (TS) (without leaves and buds) were collected from the periphery and top of the canopy during the middle of the calendar months, i.e. from 15 January to 15 December. Flower buds (FB) were also collected from all types of bearing shoots during the middle of each month, from 15 August until 15 March of the following year. The flower buds were identified using dissection under the microscope. Flowers (FL) were collected at the full flowering stage. A 2-cm-long segment from each sample of OS and TS, and $20 \mathrm{FB}$ and FL in three replicates were analyzed for sodium $(\mathrm{Na})$ content. The each samples were dried at $105^{\circ} \mathrm{C}$ to constant weight. After this, the samples were ashed for chemical analysis at $550^{\circ} \mathrm{C}$ for 24 hours. The white ash was made up to $50 \mathrm{ml}$ with redistilled water. The Na was determined by atomic absorption spectrophotometry (AAS) using a Pye Unicam SP 191 atomic absorber. Data are given as \% of dry weight (d.w.).
For a period of three harvest seasons, 20 fruits from each cultivar of each of three replicates were collected and their fruit weight (FW) were determined using a Tehnica ET-1111 technical scale (Iskra, Slovenia). An ACS System Electronic Scale (Zhejiang, China) was used to measure fruit yield per tree and hectare $(\mathrm{kg})$, respectively.

\section{Statistical analysis}

The obtained data were analysed according to a factorial design arranged in a randomised complete block design with three replicates, with the rootstock, cultivar, shoot age and year being factors, with four and/or three levels each (rootstock: Myrobalan and Stanley; cultivar: 'Cacanska Lepotica' and 'Cacanska Najbolja'; shoot age: 1-year-old and 2-year-old; year: 2006, 2007 and 2008). Analysis of variance (ANOVA) was performed at a significance level $P \leq 0.05$, followed by a LSD test at $P \leq 0.05$ using the MSTAT-C statistical package (Michigan State University, East Lansing, MI, USA).

The relationship between each plum organ regarding $\mathrm{Na}$ content was evaluated by Pearson's product moment correlation at $P \leq 0.05$. A Principal Component Analysis (PCA) was performed to determine the relationships among rootstock/ cultivar combinations and among variables using the PRINCOMP procedure of the SAS statistical package (SAS Institute Inc., North Carolina, USA).

\section{Results and Discussion}

\section{Evaluation of soil properties}

The plum orchard soil was cambisol (USDA SOIL TAXONOMY, 1999) with sandy-loam texture. It is generally distributed in north-west and west Serbia (TANASIJEVIC et al., 1966). Table 2 shows soil test results from the samples taken in 2006-2008. The soil pH was very low and ranged from 3.19 to 4.31. Cambisol in above region of Serbia are characterised by significantly pronounced 
acidity (PROTIC et al., 2003). Moreover, the soil had low to moderate organic matter supply $(0.18$ to $2.22 \%$ ) and a very low $\mathrm{N}_{\text {тот }}$ content $(0.01$ to $0.14 \%)$, which is in agreement with previous work (MILOŠEVIĆ; MILOŠEVIĆ, 2010). The contents of available $\mathrm{P}_{2} \mathrm{O}_{5}$ and $\mathrm{K}_{2} \mathrm{O}$ in the $0-60 \mathrm{~cm}$ soil depth were low and modearte, respectively. These values ranged from 10.1 to $34.1 \mathrm{mg} \mathrm{kg}^{-1}$ and 198.1 to 270.1 $\mathrm{mg} \mathrm{kg}^{-1}$, respectively, and gradually decreased with depth. The contents of $\mathrm{CaO}, \mathrm{MgO}$ and $\mathrm{Na}_{2} \mathrm{O}$ in the said soil depth were $0.39-0.73 \%, 1.41-2.34 \%$ and $0.61 \%-0.68 \%$, respectively, and gradually increased with depth; these values shows that the soil has high cation exchangeable capacity (CEC), as previously reported (PROTIC et al., 2003). In addition, electrical conductivity (EC) of soil sample ranged from 0.74 to $1.73 \mathrm{dS} \mathrm{m}^{-1}$ (Table 2), indicating that there is no salinity risk to soil, since no value is up to $4.0 \mathrm{dS} \mathrm{m}^{-1}$, which is the critical limit for more crops (JAISMAL, 2003). For example, EC threshold for yield reduction for plum growing in sandy and/or loam soils ranged from 1.5 to $2.5 \mathrm{dS} \mathrm{m}^{-1}$ (XU et al., 2000). Finally, the content of $\mathrm{CaO}, \mathrm{MgO}$ and $\mathrm{Na}_{2} \mathrm{O}$ were low, and did not reach the levels considered "normal" for the cambisol soil with sandy-loam texture in Serbia (PROTIC et al., 2003).

Table 2. Soil chemical properties at different soil depths.

\begin{tabular}{lcccc}
\hline \multirow{2}{*}{ Soil properties $^{*}$} & \multicolumn{4}{c}{ Soil depth (cm) } \\
\cline { 2 - 4 } & $\mathbf{0 0 - 2 0}$ & $\mathbf{2 1 - 4 0}$ & $\mathbf{4 1 - 6 0}$ & $\mathbf{6 1 - 8 0}$ \\
\hline $\mathrm{pH}_{\mathrm{KCl}}$ & 4.31 & 4.12 & 3.83 & 3.19 \\
Organic matter $(\%)$ & 2.22 & 0.74 & 0.51 & 0.18 \\
$\mathrm{~N}_{\text {TOT }}(\%)$ & 0.14 & 0.04 & 0.02 & 0.01 \\
$\mathrm{P}_{2} \mathrm{O}_{5}\left(\mathrm{mg} \mathrm{kg}^{-1}\right)$ & 34.1 & 26.9 & 13.1 & 10.1 \\
$\mathrm{~K}_{2} \mathrm{O}\left(\mathrm{mg} \mathrm{kg}^{-1}\right)$ & 270.1 & 243.1 & 201.2 & 198.1 \\
$\mathrm{CaO}(\%)$ & 0.39 & 0.43 & 0.61 & 0.73 \\
$\mathrm{MgO}(\%)$ & 1.41 & 1.52 & 2.27 & 2.34 \\
$\mathrm{Na}_{2} \mathrm{O}(\%)$ & 0.61 & 0.63 & 0.67 & 0.68 \\
Electrical conductivity $\left.(\mathrm{dS} \mathrm{m})^{-1}\right)$ & 0.74 & 1.32 & 1.73 & 1.43 \\
\hline
\end{tabular}

*Soil sampling for chemical analysis was conducted in mid-November 2006, 2007 and 2008 (average values).

Source: Elaboration of the authors.

\section{Changes in the shoot content of $\mathrm{Na}$ during year}

The effect of rootstock on changes in the shoot content of $\mathrm{Na}$ in plum cultivars was evaluated during year. Both similarities and differences were observed in the intensity of change in the ion content as dependent upon rootstock/cultivar combination (Figure 1). Namely, the mean content of $\mathrm{Na}$ in $\mathrm{OS}$ in all rootstock/cultivar combinations decreased from January to March, only to intensively accumulate thereafter reaching the maximum level in May. Then, the content of $\mathrm{Na}$ decreased until July and slightly increased until November. Thereafter, the
Na content of OS in 'Cacanska Najbolja' on both rootstocks decreased until December, and that in 'Cacanska Lepotica' on the above rootstocks increased.

A similar trend was observed for $\mathrm{Na}$ content in TS (Figure 2). The Na content decreased from January to February, but increased thereafter until May and June. It reached the second lowest accumulation level during the year in July and increased in July and August. Then, the content slightly decreased in all rootstock/cultivar combinations reaching its average value in December (Figure 2). 
Figure 1. Changes in the sodium content of 1-year-old plum shoots.

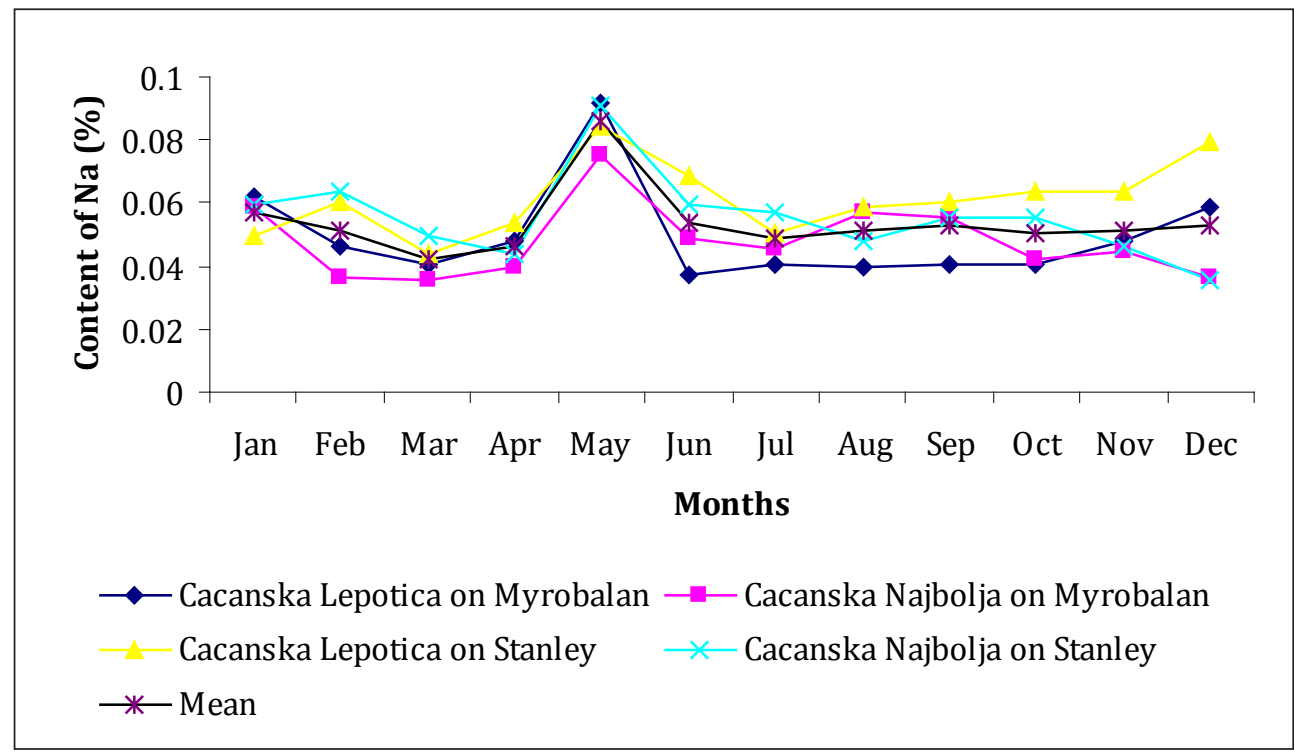

Source: Elaboration of the authors.

Figure 2. Changes in the sodium content of 2-year-old plum shoots.

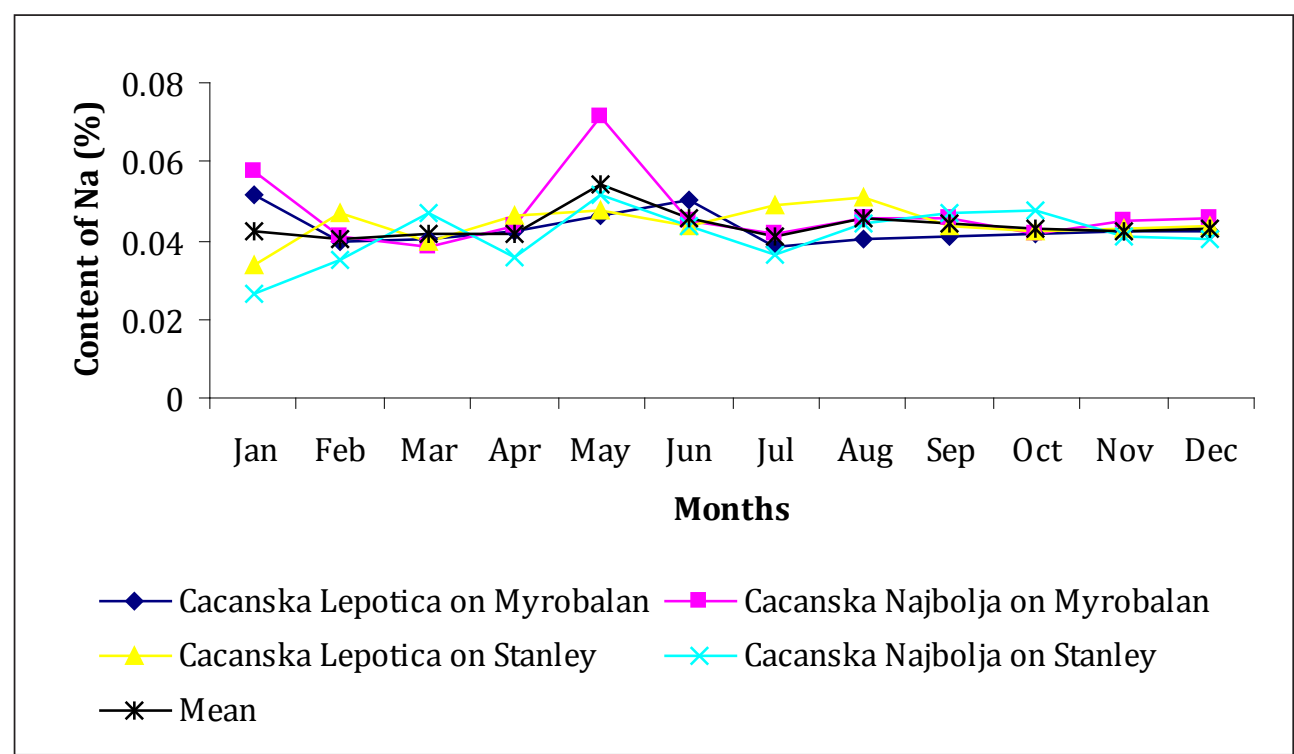

Source: Elaboration of the authors.

The $\mathrm{Na}$ content of shoots was affected by rootstock, cultivar, shoot age and year. It was higher on Stanley rootstock than Myrobalan (Table 3). The Na content of shoots was higher in 'Cacanska
Lepotica' and lower in 'Cacanska Najbolja'. More $\mathrm{Na}$ was found in OS than in TS. The content of $\mathrm{Na}$ was significantly higher in the first and second years as compared to the third year. 
Table 3. The effect of rootstock, cultivar, shoot age and year on the sodium content of 1-year-old and 2-year-old shoots (mean $\pm \mathrm{SE}$ ).

\begin{tabular}{lc}
\hline Treatment & $\begin{array}{c}\text { Content of sodium } \\
\text { (\% of dry weight) }\end{array}$ \\
\hline Roostock (A) & $0.044 \pm 0.002 \mathrm{~b}$ \\
Myrobalan & $0.050 \pm 0.004 \mathrm{a}$ \\
Stanley & \\
Cultivar (B) & $0.049 \pm 0.003 \mathrm{a}$ \\
Cacanska Lepotica & $0.045 \pm 0.003 \mathrm{~b}$ \\
Cacanska Najbolja & \\
Shoot age (C) & $0.053 \pm 0.003 \mathrm{a}$ \\
1-year-old shoots & $0.041 \pm 0.001 \mathrm{~b}$ \\
2-year-old shoots & \\
& \\
Year (D) & $0.049 \pm 0.003 \mathrm{a}$ \\
2007 & $0.049 \pm 0.003 \mathrm{a}$ \\
2008 & $0.044 \pm 0.002 \mathrm{~b}$ \\
2009 & \\
ANOVA & $*$ \\
Rootstock (A) & $*$ \\
Cultivar (B) & $*$ \\
Shoot age (C) & $*$ \\
Year (D) & $*$ \\
A $\times$ B $\times$ C & $*$ \\
A $\times$ B $\times$ D & $*$ C $\times$ D \\
B $\times$ C $\times$ D & $*$ \\
A $\times$ B $\times$ C $\times$ D & \\
\hline
\end{tabular}

$\mathrm{A}, \mathrm{B}, \mathrm{C}$ and D represent 'Rootstock', 'Cultivar', 'Shoot age' and 'Year' treatment, respectively.

The same letter(s) in column indicate non-significant differences between means at $P \leq 0.05$ by LSD test.

The asterisk in column indicates a significant difference between means at $P \leq 0.05$ by LSD test. ns: non-significant differences.

Source: Elaboration of the authors.

The shoot content of $\mathrm{Na}$ varied across rootstock/ cultivar combinations during calendar year; the highest levels in OS being recorded two times, i.e. in winter and spring and the lowest at the end of winter and summer (Figure 1). The increase in the content of $\mathrm{Na}$ during winter coincided with the driest period and was probably related to the loss of weight of senescent leaves (data not shown) and/or decrease in leaching, as previously reported in the literature (PALMA et al., 2000). During the period of yellowing, there is a steady outward movement of mobile elements such as $\mathrm{Na}$ from the leaves. Montagnini (1990) stated that seasonal changes in the levels of nutrients, including also $\mathrm{Na}$, in fruit trees largely depend on the bioelement cycle, tree development stage and climate and soil factors. These variations in nutrient content were greater in leaves than in shoots and fruits (CANNEL; KIMEU, 1971; PALMA et al., 2000; SOARES et al., 2008). The present study suggests that $\mathrm{Na}$ displayed the greatest seasonality in shoots, possibly due to its being the most mobile element (HELMISAARI, 1992).

Rootstocks can have profound effects on scions such as controlling the nutrient composition of the plant (BOYHAN et al., 1998; JIMÉNEZ et al., 2004). Statistically significant differences were observed in our study $(P \leq 0.05)$ between rootstocks, cultivars, shoot age and year in the shoot content of $\mathrm{Na}$ as well as in its seasonal changes (Table 3, Figure 1). However, the content of $\mathrm{Na}$ in plum shoots was significantly affected by all treatment interactions, excepting the rootstock/cultivar/shoot age/year interaction. The significant treatment interactions suggested that the levels of $\mathrm{Na}$ accumulation in the shoots were not mutually proportional across years. Jiménez et al. (2007) showed the significant effect of rootstock on the shoot content of $\mathrm{Na}$ in sweet cherry trees. Similar results were obtained by Hofman et al. (2002), Daza et al. (2008) and Rato et al. (2008), who reported an important role of rootstock/scion interaction on tree nutritional status.

In mature trees, wood makes up a large proportion of plant volume. For mature plum trees, wood thus provides a large volume of tissue for the accumulation of $\mathrm{Na}$ (ZISKA et al., 1991). The differences between OS and TS tissues in Na content in the present study (Table 3) suggest the functional role of shoots in preventing $\mathrm{Na}$ accumulation in the leaf, which is in agreement with previous work (CANNEL; KIMEU, 1971; BOLAND; JERIE; 
MAAS, 1997). If mechanisms of $\mathrm{Na}$ absorption by roots (RAINS; EPSTEIN, 1965; CHEESMAN, 1988) and mechanisms of $\mathrm{Na}$ transport to the leaf are excluded, the increased leaf content of $\mathrm{Na}$ may be toxic to fruit crops. Lauchli (1984) reported that roots or stems, or both, have a mechanism that controls the rate of $\mathrm{Na}$ ion transport to the leaf.

Stanley rootstock had a less effective control mechanism of $\mathrm{Na}$ accumulation in OS and TS as compared to Myrobalan (Table 3). Rootstocks, i.e. their root, play an important role in the uptake, distribution, compartmentalisation and accumulation of $\mathrm{Na}$ in fruit crop organs and tissues (WEST, 1978). Singh and Sharma (2005) reported that rootstock affected the ion concentrations in the leaves and other organs of the scion. Matsumoto et al. (2008) suggested that the native Mediterranean pear rootstock may have some salt exclusion mechanisms in the shank which restrict Na transport to the scion woods and, especially, the leaves. In study on the salinity tolerance of three vegetative rootstocks of plum (Marianna GF 8-1, Myrobolan B, and Pixy), Bolat et al. (2006) determined that Pixy had a much lower Na level. Moreover, they reported that accumulation of $\mathrm{Na}$ in roots and leaves indicates a possible mechanism whereby Pixy copes with salinity in the rooting medium, and/or may indicate the existence of an inhibition mechanism of $\mathrm{Na}$ transport to scion woods and leaves; therefore, valuable information regarding rootstock effect is given by this parameter, for peach (MASSAI; GUCCI; TATTINI, 1998; SOTIROPOULOS et al., 2006), Rosa spp. (CABRERA, 2002), citrus (GARCÍA-SÁNCHEZ et al., 2005), almond (NAJAFIAN; RAHEMI; TAVALLALI, 2008) and cashew (FERREIRA-SILVA et al., 2008).

The present study revealed that the shoots of 'Cacanska Lepotica' had a significantly higher content of $\mathrm{Na}$ than the shoots of 'Cacanska Najbolja' at $P \leq 0.05$ (Table 3). Different genotypes of plum, peach and avocado show different levels of $\mathrm{Na}$ accumulation in woody tissues, as previously reported in the literature (NASR; EL-AZA; EL-
SHURAFA， 1977; CASTRO; ITURRIETA; FASSIO, 2009). The significant rootstockcultivar interaction $(P \leq 0.05)$ with respect to $\mathrm{Na}$ accumulation in plum shoots in this study serves as a confirmation of the results obtained by Nasr, ElAza and El-Shurafa (1977).

The OS had a significantly higher content of $\mathrm{Na}$ as compared to TS at $P \leq 0.05$ (Table 3, Figure 2). This content was $22.64 \%$ higher. Similar values were reported by Najafian, Rahemi and Tavallali (2008) for Na levels in almond shoots. However, Jiménez et al. (2007) found substantially lower levels of $\mathrm{Na}$ in cherry shoots as compared to the values herein obtained. The differences may be due to specific characteristics of fruit species, cultivars, climate and soil conditions, primarily the water status in soil, woody tissue and leaf (ZARROUK et al., 2005).

The literature provides different and, often, inconsistent data on ion distribution schemes between woody tissues and other organs, especially leaves. Castro, Iturrieta and Fassio (2009) showed that roots accumulated a higher $\mathrm{Na}$ content than the old and new leaves, whereas Ziska et al. (1991) reported that the trunk and branches provided a much greater volume of tissue for ion retention than the small roots and twigs. The above authors also suggested that, despite the higher concentrations of $\mathrm{Na}$ in roots and twigs than in trunks and branches, the greatest quantity of these ions must have been in the trunk and branches, which was confirmed by the present results.

Significantly higher $(P \leq 0.05)$ levels of $\mathrm{Na}$ in plum shoots were registerd in the first and second years than in the third year of the experiment (Table 3 ), which is in agreement with the results obtained by Bernstein, Brown and Hayward (1956) in their four-year study on the distribution of $\mathrm{Na}$ between woody tissues and leaves in young Prunus salicina trees on Marianna rootstock. The data presented in Table 1 show that rainfall was higher in the first experimental year than in the second year, 
as compared to the long-term period. Namely, some authors reported that climatic conditions can have a significant effect on soil salinity through both rainfall amount and distribution and air temperature. For example, during dry years or dry periods of the growing season characterised by high air temperatures, plant water requirements increase and tolerance to salts, most notably $\mathrm{Na}$, decreases (DRAGOVIĆ; BOŽIĆ; STEVIĆ, 2007). Excessive rainfall can also contribute to soil salinity through an increase in groundwater level in the root zone and, hence, soluble salts, in case of saline groundwater (JAISMAL, 2003).

Changes in the flower bud and flower contents of $\mathrm{Na}$ during season

All rootstocks showed relative changes in the content of $\mathrm{Na}$, when they were grafted with both cultivars during August-March (Figure 3). The highest content of $\mathrm{Na}$ in FB during AugustMarch was in August. It decreased thereafter to a minimum of $0.030 \pm 0.001 \%$ in October. Then, the content showed an increasing tendency, reaching $0.039 \pm 0.001 \%$ in March. The data given in Table 4 show that the Stanley rootstock and cv. 'Cacanska Najbolja' induced a higher $\mathrm{Na}$ content of FB as compared to Myrobalan rootstock and cv. 'Cacanska Lepotica'. The content of $\mathrm{Na}$ was higher in 2006/07 than in 2007/08 and 2008/09. The FL content of $\mathrm{Na}$ at the full flowering stage was higher than the shoot and flower bud contents (Figure 4), ranging from $0.028 \pm 0.003 \%$ in 'Cacanska Najbolja' on Stanley to $0.059 \pm 0.009 \%$ in 'Cacanska Lepotica' on Myrobalan rootstock.

The highest levels in FB were recorded in mid-summer and the lowest in autumn (Figure 3), which was in agreement with the mobility of $\mathrm{Na}$ throughout the season (HELMISAARI, 1992). This study showed statistically significant differences $(P$ $\leq 0.05$ ) between rootstocks, cultivars and years in $\mathrm{Na}$ content and its changes in FB during the season (Table 4). However, there was a significant $(P \leq 0.05)$ effect of the rootstock/cultivar/year interaction on the content of $\mathrm{Na}$ in shoots and other organs, which is in accordance with previous studies in fruit trees (BOYHAN et al., 1998; HOFMAN et al., 2002; RATO et al., 2008).

Table 4. The effect of rootstock, cultivar and year on the sodium content of flower buds (mean $\pm \mathrm{SE}$ ).

\begin{tabular}{lc}
\hline Treatment & $\begin{array}{c}\text { Content of sodium } \\
\text { (\% of dry weight) }\end{array}$ \\
\hline Rootstock (A) & $0.037 \pm 0.001 \mathrm{~b}$ \\
Myrobalan & $0.040 \pm 0.001 \mathrm{a}$ \\
Stanley & \\
Cultivar (B) & $0.038 \pm 0.001 \mathrm{~b}$ \\
Cacanska Lepotica & $0.039 \pm 0.001 \mathrm{a}$ \\
Cacanska Najbolja & \\
& \\
Year (C) & $0.039 \pm 0.001 \mathrm{a}$ \\
2007 & $0.038 \pm 0.001 \mathrm{~b}$ \\
2008 & $0.038 \pm 0.001 \mathrm{~b}$ \\
2009 & \\
ANOVA & $*$ \\
Rootstock (A) & $*$ \\
Cultivar (B) & $*$ \\
Year (C) & $*$ \\
A $\times$ B & $*$ \\
A $\times$ C & $*$ \\
B $\times$ C & $*$ B $\times$ C \\
\hline
\end{tabular}

$\mathrm{A}, \mathrm{B}$ and $\mathrm{C}$ represent 'Rootstock', 'Cultivar' and 'Year' treatment, respectively.

The same letter(s) in column indicate non-significant differences between means at $\mathrm{P} \leq 0.05$ by LSD test.

The asterisk in column indicates a significant difference between means at $\mathrm{P} \leq 0.05$ by LSD test.

Source: Elaboration of the authors. 
Figure 3. Changes in the sodium content of plum flower buds.

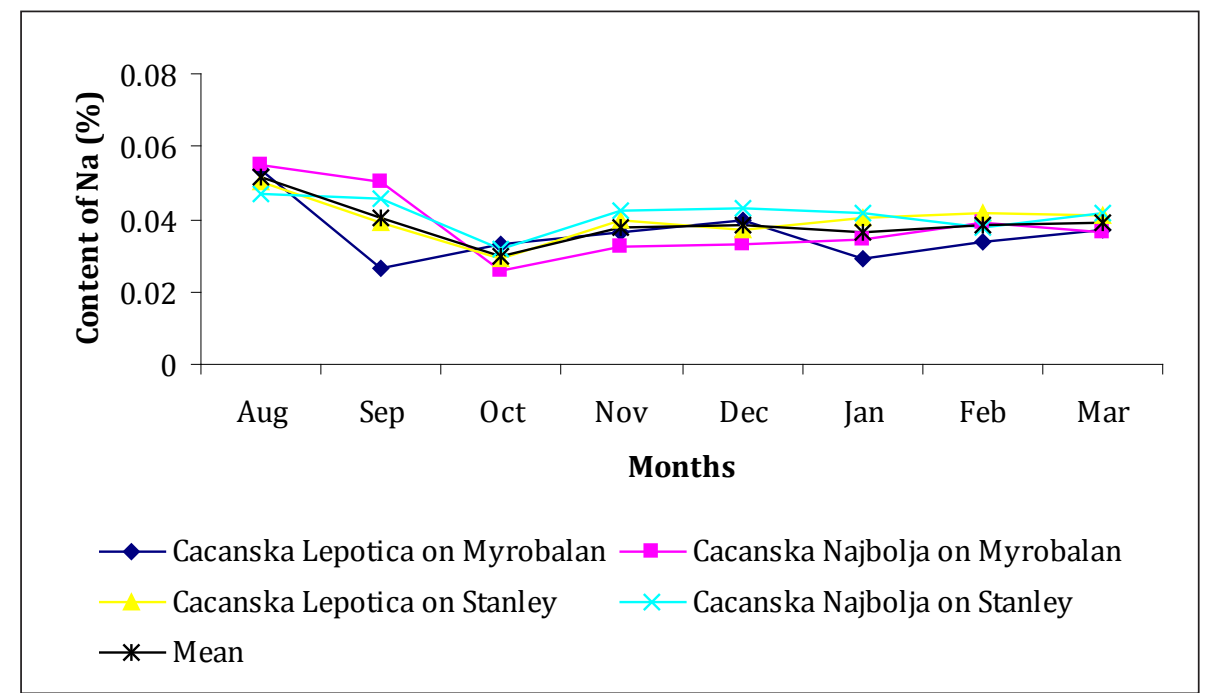

Source: Elaboration of the authors.

Floral analyses, as an early tool to allow the diagnosis of potential deficiencies or excesses, have been recently conducted (SANZ; MONTAÑÉS, 1995; ABADÍA et al., 2000). Ghanem et al. (2009) reported that $\mathrm{Na}$ accumulated in style, ovaries and anther intermediate layers but not in the tapetum nor in the pollen. There were statistically significant differences $(P \leq 0.05)$ in the present study among rootstock/cultivar combinations in $\mathrm{Na}$ content of
FL (Figure 4). Betrán et al. (1997) reported that the range of variation of $\mathrm{Na}$ ion in flowers, among rootstocks, was higher than leaves and other organs. Additionally, apart from rootstock, species and/ or genotypes play a key role in determining the $\mathrm{Na}$ content in the flowers of fruit crops, which is in agreement with previous work in flower (ZARROUK et al., 2005).

Figure 4. Sodium content in plum flowers. The same letter(s) at the top of the columns indicates non significant differences at $P \leq 0.01$ by LSD test.

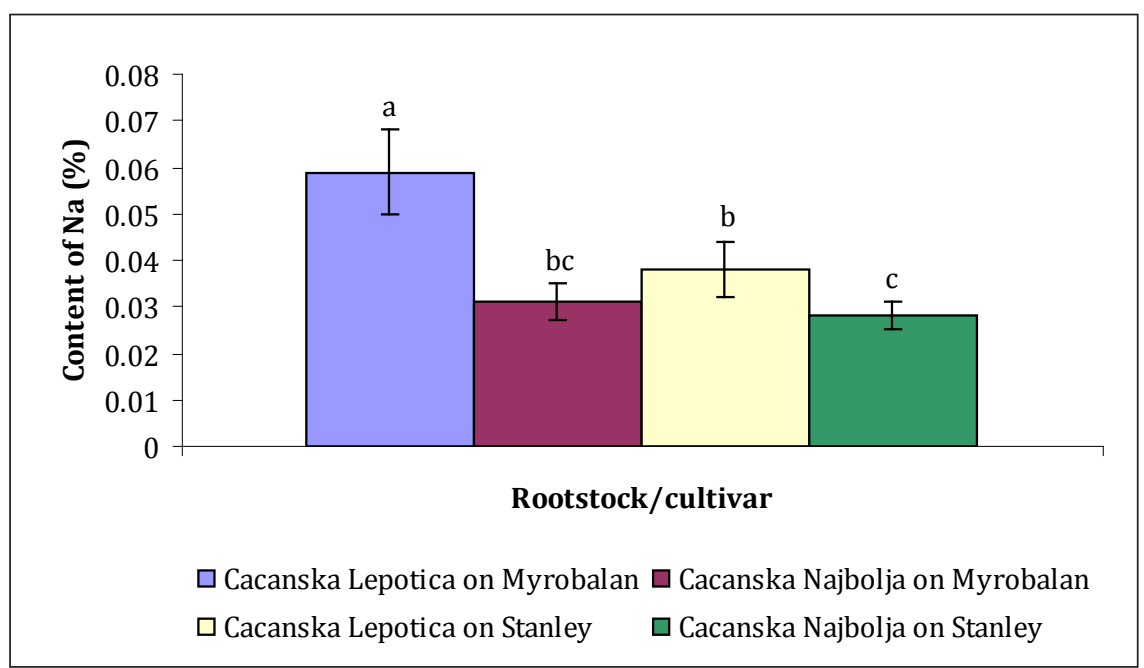

Source: Elaboration of the authors. 
The average content of $\mathrm{Na}$ in plum organs suggested the following trends: 1-year old shoots $>$ 2-year-old shoots $>$ flower buds $>$ flower (JIMÉNEZ et al., 2004).

Evaluation of correlations among variables and principal component analysis (PCA)

The data given in Table 5 show correlations among the plum organs as regards $\mathrm{Na}$ content. However, the correlations were not statistically significant. It confirms that $\mathrm{Na}$ content in plant tissues, including plum tree, is a complex parameter determined by numerous characteristics such as soil type and texture, contents of soil $\mathrm{K}, \mathrm{Ca}, \mathrm{Mg}$ and $\mathrm{Na}$ and their ratio, amounts of rainfall, field water capacity, air temperature, crop species and cultural practices, i.e. irrigation (BERNSTEIN; BROWN; HAYWARD, 1956; XU et al., 2000). In addition, Zarrouk et al. (2005) indicated that only flower Zn concentration in peach was significantly correlated with $\mathrm{Zn}$ in leaves, as opposed to the other nonsignificant correlations. Similar data were reported by Sanz and Montañés (1995) for peach and Betrán et al. (1997) and Jiménez et al. (2004) for cherry.

Table 5. Correlation matrix among the studied variables.

\begin{tabular}{lcccc}
\hline Variable & OS & TS & FB & FL \\
\hline OS & 1.000 & & & \\
TS & $0.638 \mathrm{~ns}$ & 1.000 & & \\
FB & $0.795 \mathrm{~ns}$ & $0.066 \mathrm{~ns}$ & 1.000 & \\
FL & $-0.261 \mathrm{~ns}$ & $0.561 \mathrm{~ns}$ & $-0.788 \mathrm{~ns}$ & 1.000 \\
\hline
\end{tabular}

Abbreviations: OS: 1-year-old shoots; TS: 2-year-old shoots; FB: flower buds; FL: flowers.

ns: non-significant correlations.

Source: Elaboration of the authors.

A PCA, one of the multivariate statistical procedures, was used to establish relationships among shoots, flower buds and flowers and to study correlations regarding $\mathrm{Na}$ content within sets of rootstock/cultivar combination. The PCA carried out in this study showed that more than $90 \%$ of the variability observed was explained by the two components (Table 6). PC1 and PC2 accounted for $56.68 \%$ and $42.98 \%$, respectively of the variability.

Figure 5 represents $\mathrm{PC} 1$ and $\mathrm{PC} 2$ plotted on a bidimensional plane. The highest positive values for PC1 indicated the rootstock/cultivar combinations giving the highest content of $\mathrm{Na}$ in $\mathrm{OS}$ and $\mathrm{FB}$ ('Cacanska Lepotica' on Stanley and 'Cacanska Najbolja' on Stanley), as shown in Figure 5. The highest PC2 values refer to the rootstock/cultivar combinations producing the highest content of $\mathrm{Na}$ in TS, such as 'Cacanska Lepotica' on Stanley and the highest content of $\mathrm{Na}$ in FL in 'Cacanska Lepotica' on both rootstocks.

The principal component analysis (PCA) used in this study showed that 'Cacanska Lepotica' on Stanley rootstock had a higher capacity for $\mathrm{Na}$ accumulation and distribution within shoots, FB and FL, as compared to the other rootstock/cultivar combinations (Table 6, Figure 5). However, no completely clear situation can be established from the results obtained in this work. In fact, it seems that the effects of different rootstocks on $\mathrm{Na}$ content show a strong interaction with the year, as a variable or even opposite behaviour is observed in each year, which is in accordance with the previous work in plum trees (DAZA et al., 2008).

Table 6. Eigenvalues and the proportion of total variability among rootstock/cultivar combinations as explained by the three principal components.

\begin{tabular}{lccc}
\hline PC & Eigenvalues & $\begin{array}{c}\text { Percent } \\
\text { variance }\end{array}$ & $\begin{array}{c}\text { Cumulative } \\
(\%)\end{array}$ \\
\hline 1 & 2.267 & 56.685 & 56.685 \\
2 & 1.719 & 42.982 & 99.667 \\
3 & 0.013 & 0.333 & 100.000 \\
\hline
\end{tabular}

Source: Elaboration of the authors. 
Figure 5. Segregation of four plum rootstock/cultivar combinations according to their effect on $\mathrm{Na}$ content in 1-year-old (OS) and 2-year-old shoots (TS), flower buds (FB) and flowers (FL) determined by principal component analysis (PCA).

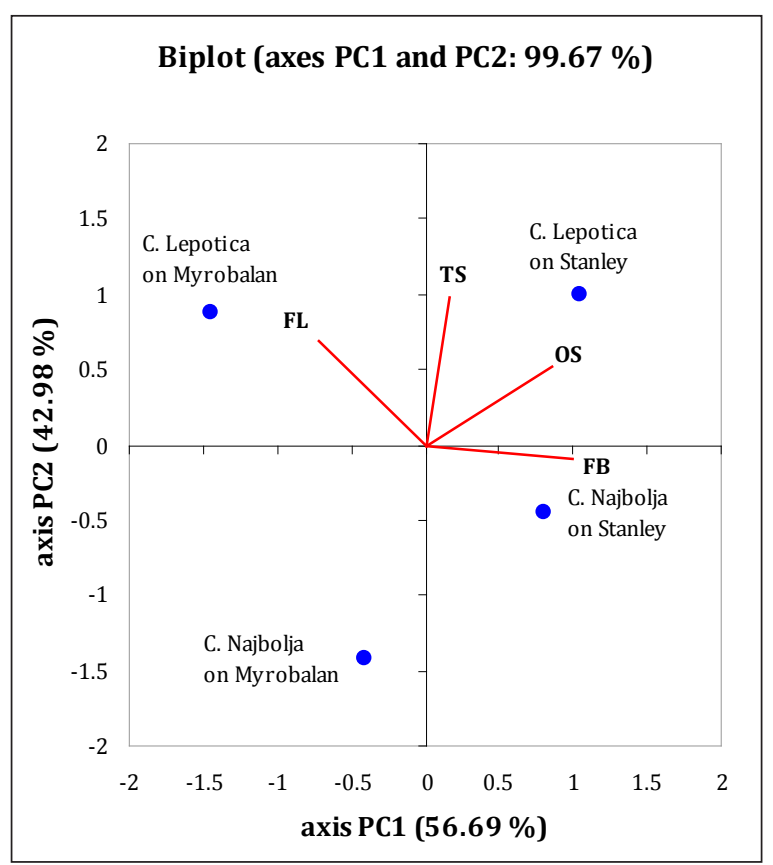

Source: Elaboration of the authors.

\section{Evaluation of fruit weight and yield of plum}

The FW among cultivars ranged from 50.80 g ('Cacanska Najbolja') to 48.30 g ('Cacanska Lepotica') and differences were significant (Table 7). Differences among rootstocks for FW also were registered and varied from $48.74 \mathrm{~g}$ (Myrobalan) to $50.36 \mathrm{~g}$ (Stanley). Cultivar/rootstock interaction were not oserved. Previous work on plum in HDP system also reported a high variability among cultivars regarding this parameter (SOSNA, 2002; MELAND, 2005; PEPPELMAN et al., 2007). There were significant difference in yield per tree and unit area among cultivars (Table 7).

The average yield per tree and hectare were higher in 'Cacanska Najbolja' than in 'Cacanska Najbolja'. Effect of rootstocks and cultivar/rootstock interaction on these properties were not observed, which is in accordance with previous work carried out in plum (SOSNA, 2002). Based on the results obtained in our study it can be said that the content of $\mathrm{Na}$ in the main organs of plum trees and acidic soil have not a negative effect on fruit size and yield of plum cultivars, since these properties were very respectable. In other words, the $\mathrm{Na}$ content in the soil and plum organs did not limit normal vegetative and reproductive growth.

Table 7. Average fruit weight and yield of two plum cultivars grafted on Myrobalan and Stanley seedlings rootstocks during three successive years.

\begin{tabular}{lccc}
\hline Treatment & $\begin{array}{c}\text { Fruit weight } \\
\text { (g) }\end{array}$ & $\begin{array}{c}\text { Yield per tree } \\
\left(\mathbf{k g ~ h a}^{-1}\right)\end{array}$ & $\begin{array}{c}\text { Yield per hectare } \\
\left(\mathbf{t ~ h a}^{-1} \mathbf{)}\right.\end{array}$ \\
\hline Cultivar (A) & & & \\
Cacanska Lepotica & $48.30 \mathrm{~b}$ & $14.70 \mathrm{~b}$ & $18.37 \mathrm{~b}$ \\
Cacanska Najbolja & $50.80 \mathrm{a}$ & $16.70 \mathrm{a}$ & $20.87 \mathrm{a}$ \\
& & & \\
Rootstock (B) & & \\
Myrobalan & $48.74 \mathrm{~b}$ & $15.27 \mathrm{a}$ & $19.09 \mathrm{a}$ \\
Stanley & $50.36 \mathrm{a}$ & $16.18 \mathrm{a}$ & $20.22 \mathrm{a}$ \\
& & & \\
ANOVA & & & $*$ \\
Cultivar (A) & $*$ & $\mathrm{n}$ & $\mathrm{ns}$ \\
Rootstock (B) & $*$ & $\mathrm{~ns}$ & $\mathrm{~ns}$ \\
A $\times$ B & $\mathrm{ns}$ & $\mathrm{ns}$ & \\
\hline
\end{tabular}

†Values for fruit weight and yield are related to the average for 2006, 2007 and 2008. A and B represent 'Cultivar' and 'Rootstock' treatment, respectively. The asterisk in columns indicates a significant difference between means at $P \leq 0.05$ by LSD test. Data with the same letter(s) in columns are not significantly different at $P \leq 0.05$ by LSD test. ns: non-significant differences.

Source: Elaboration of the authors. 


\section{Conclusions}

The content of $\mathrm{Na}$ in the shoots and flower buds of each rootstock/cultivar combination varied throughout the year, being substantially affected by rootstocks, cultivars, shoots age and years. However, the statistically significant interactions observed between each treatment suggest that the levels of $\mathrm{Na}$ accumulation in shoots, flower buds and flowers were not mutually proportional. Based on the above observations, this work suggests that Myrobalan rootstock had a lower $\mathrm{Na}$ accumulation capacity and, hence, a better control mechanism of its distribution in woody tissues and transport to other organs. Moreover, shoots and flower buds can be considered major reservoirs of $\mathrm{Na}$. Along with the flower, they have a substantial capacity to compartmentalise $\mathrm{Na}$. No significant correlation in $\mathrm{Na}$ content between the shoots, flower buds and flowers were observed. The PCA revealed that the Stanley rootstock had better performance than Myrobalan in terms of the accumulation and distribution of $\mathrm{Na}$ within plum tree organs. The content of $\mathrm{Na}$ in the plum organs evaluated and acidic soil have not a negative effect on fruit weight and yield of cultivars, since these properties were very respectable.

\section{References}

ABADÍA， J.; TAGLIAVINI, M.; GRASA, R.; BELKHODJA, R.; ABADÍA, A.; SANZ, M.; ARAUJO E.; TSIPOURIDIS, C.; MARANGONI, B. Using the flower Fe concentration for estimating chlorosis status in fruit tree orchards: a summary report. Journal of Plant Nutrition, Philadelphia, v. 23, n. 11-12, p. 2023-2033, 2000.

ANONIMOUS. Sodium - Na. the tortoise shell "science of health" newsletter. 2010. Available at: <http://www. hbci.com/ wenonah/hydro/na.htm.>. Accessed at: 23 mar. 2010.

ASHRAF, M.; AHMAD, S. Influence of sodium on ion accumulation, yield components and fibre characteristics in salt-tolerant and salt-sensitive lines of cotton (Gossypium hirsutum L.). Field Crops Research, Amsterdam, v. 66, n. 2, p. 115-127, 2000.
BERNSTEIN, L.; BROWN, J. W.; HAYWARD H. E. The influence of rootstock on growth and salt accumulation in stone-fruit trees and almonds. Proceedings of American Society for Horticultural Science, Geneva, v. 68, n. 1, p. 86-95, 1956.

BETRÁN, J. A.; VAL, J.; MONTAÑÉS MILLÁN, L.; MONGE, E.; MONTAÑÉS, L.; MORENO, M. A. Influence of rootstock on the mineral concentrations of flowers and leaves from sweet cherry. Acta Horticulturae, Leuven, v. 448, n. 1, p. 163-168, 1997.

BOLAND, A. M.; JERIE, P.; MAAS, E. Long-term effects of salinity on fruit trees. Acta Horticulturae, Leuven, v. 449, n. 1, p. 599-606, 1997.

BOLAT, I.; KAYA, C.; ALMACA, A.; TIMUCIN, S. Calcium sulphate improves salinity tolerance in rootstocks of plum. Journal of Plant Nutrition, Philadelphia, v. 29, n. 3, p. 553-564, 2006.

BOYHAN, E. G.; NORTON, J. D.; PITTS, J. A.; HIMELRICH, D. G. Growth, yield, survival and leaf nutrient concentrations of plums on various rootstocks. Fruit Varieties Journal, Summerland, v. 52, n. 2, p. 7179, 1998.

CABRERA, I. R. Rose yield, dry matter partitioning and nutrient status responses to rootstock selection. Scientia Horticulturae, Amsterdam, v. 95, n. 1-2, p. 275-83, 2002.

CANNEL, M. G. R.; KIMEU, B. S. Uptake and distribution of micro-nutrients in trees of Coffea arabica L. in Kenya as affected by seasonal climatic differences and the presence of fruits. Annals of Applied Biology, London, v. 8, n. 2, p. 213-230, 1971.

CASTRO, V. M.; ITURRIETA, E. R.; FASSIO, O. C. Rootstock effect on the tolerance of cv. Hass avocado plants to $\mathrm{NaCl}$ stress. Chilean Journal of Agricultural Research, Chillán, v. 69, n. 3, p. 316-324, 2009.

CATLIN, P. B.; HOFFMAN, G. J.; MEAD, R. M.; JOHNSON, R. S. Long-term response of mature plum trees to salinity. Irrigation Science, New York, v. 13, n. 4, p. 171-176, 1993.

CHEESMAN, J. M. Mechanism of salinity tolerance in plants. Plant Physiology, Palo Alto, v. 87, n. 3, p. 547550, 1988

DAZA, A.; GARCÍA-GALAVÍS, A. P.; GRANDE, J. M.; SANTAMARÍA, C. Fruit quality parameters of 'Pioneer' Japanese plums produced on eight different rootstocks. Scientia Horticulturae, Amsterdam, v. 118, n. 3, p. 206211, 2008

DRAGOVIĆ, S.; BOŽIĆ, M.; STEVIĆ, D. Water and salinity regime of irigated soil from salinity control 
aspect in flat Srem. Vodoprivreda, Belgrade, v. 39, n. 229-230, p. 376-390, 2007.

EGNER, H.; RIEHM, H.; DOMINGO, W. Untersuchungen u"ber die chemische Bodenanalyse als Grundlage für die Beurteilung des Nährstoffzustandes der Böden. Annals of the Royal Agricultural College of Sweden, Uppsala, v. 26, n. 1, p. 1-99, 1960.

FERREIRA-SILVA, S. L.; SILVEIRA, J. A. G.; VOIGT, E. L.; SOARES, L. S. P.; VIÉGAS, R. A. Changes in physiological indicators associated with salt tolerance in two contrasting cashew rootstocks. Brazilian Journal of Plant Physiology, Londrina, v. 20, n. 1, p. 51-59, 2008.

GARCÍA-SÁNCHEZ, F.; BOTIA, P.; FERNÁNDEZBALLESTER, G.; CERDÁ, A.; LOPEZ, V. Uptake, transport, and concentration of chloride and sodium in three citrus rootstock seedlings. Journal of Plant Nutriton, Philadelphia, v. 28, n. 11, p. 1933-1945, 2005.

GHANEM, M. E.; VAN ELTEREN, J.; ALBACETE, A.; QUINET, M.; MARTÍNEZ-ANDÚJAR, C.; KINET, J. M.; PÉREZ-ALFOCEA, F.; LUTTS, S. Impact of salinity on early reproductive physiology of tomato (Solanum lycopersicum) in relation to a heterogeneous distribution of toxic ions in flower organs. Functional Plant Biology, Collingwood, v. 36, n. 2, p. 125-136, 2009.

GHOSH, A.B.; BAJAJ, J.C.; HASSAN, R.; SINGH, D. Soil and water testing methods: a laboratory manual. Division of Soil Science and Agricultural Chemistry, New Delhi: TARL, 1983.

HELMISAARI, H. S. Nutrient retranslocation in three Pinus sylvestris stands. Forest Ecology and Management, Amsterdam, v. 51, n. 4, p. 347-367, 1992.

HOFFMAN, G. J.; CATLIN, P. B.; MEAD, R. M.; JOHNSON, R. S.; FRANCOIS, L. E.; GOLDHAMER D. Yield and foliar injury responses of mature plum trees to salinity. Irrigation Science, New York, v. 10, n. 3, p. 215-229, 1989.

HOFMAN, P. J.; VUTHAPANICH, S.; WHILEY, A.W.; KLIEBER, A.; SIMONS, D. H. Tree yield and fruit minerals concentrations influence 'Hass' avocado fruit quality. Scientia Horticulturae, Amsterdam, v. 92, n. 2, p. 113-123, 2002.

HUSSAIN, N.; ALI, A.; SARWAR, G.; MUJEEB, F.; TAHIR, M. Mechanism of salt tolerance in rice. Pedosphere, Beijing, v. 13, n. 3, p. 233-238, 2003.

JAISMAL, P. Soil, plant and water analysis. New Delhi: Kalyani Publishers, 2003. p. 21-101.

JIMÉNEZ, S.; GARÍN, A.; BETRÁN, J. A.; GOGORCENA, Y.; MORENO, M. A. Flower and leaf analysis for nutritional prognosis of sweet cherry tree, Influence of different rootstocks. Journal of Plant Nutrition, Philadelphia, v. 27, n. 4, p. 701-712, 2004.

JIMÉNEZ, S.; PINOCHET, J.; GOGORCENA, Y.; BETRÁN, J. A.; MORENO, M. A. Influence of different vigour cherry rootstocks on leaves and shoots mineral composition. Scientia Horticulturae, Amsterdam, v. 112, n. 1, p. 73-79, 2007.

KOTTEK, M.J.; GRIESER, C.; BECK, B.; RUDOLF, B.; RUBEL, F. World map of the Köppen-Geiger climate classification updated. Meteorologische Zeitschrift, Stuttgart, v. 15, n. 3, p. 259-263, 2006.

LAUCHLI, A. Salinity tolerance in plants. In: STAPLES, C. R.; TOEMIIESSON, G. A. (Ed.). Strategies for crop improvement. New York: Wiley, 1984. p. 171-187.

MAATHUIS, M. J. F.; SANDERS, D. Sodium uptake in arabidopsis roots is regulated by cyclic nucleotides. Plant Physiology, Palo Alto, v. 127, n. 4, p. 1617-1625, 2001.

MASSAI，R.; GUCCI，R.; TATTINI， M. Salinity tolerance in four different rootstock for peach. Acta Horticulturae, Leuven, v. 465, n. 1, p. 363-370, 1998.

MATSUMOTO, K.; TAMURA, F.; JONG-PIL, C.; CAIXI, Z.; TANABE K. Influences of $\mathrm{NaCl}$ on the growth, photosynthesis, ion and water relations in rootstocks of Japanese pear. Acta Horticulturae, Leuven, v. 772, n. 1, p. 231-235, 2008.

MELAND, M. High density planting systems of European plums - the effect of growth and productivity of three cultivars after nine years. Acta Agriculturae Scandinavica, Section B - Plant Soil Science, Oslo, v. 55, n. 1, p. 51-57, 2005.

MILOŠEVIĆ, T.; MILOŠEVIĆ, N. The effect of organic fertilizer, composite NPK and clinoptilolite on changes in the chemical composition of degraded vertisol in Western Serbia. Carpathian Journal of Earth and Environmental Sciences, Baia Mare, v. 5, n. 1, p. 25-32, 2010.

MONTAGNINI, F. Ecology applied to agroforestry in the humid tropics. In: GOODLAND, R. A. (Ed.). Race to sae the tropics: ecology and economics for a sustainable future. Washington DC: Island Press, 1990. p. 49-58.

NAJAFIAN, S.; RAHEMI, M.; TAVALLALI, V. Effect of salinity on tolerance of two bitter almond rootstock. American-Eurasian Journal of Agricultural and Environmental Science, Deaira, v. 3, n. 2, p. 264-268, 2008.

NASR, T. A.; EL-AZAB, E. M.; EL-SHURAFA, M. Y. Effect of salinity and water table on growth and tolerance of plum and peach. Scientia Horticulturae, Amsterdam, v. 7, n. 3, p. 225-235, 1977. 
PALMA, R. M.; DEFRIERI, R. L.; TORTAROLO, M. F.; PRAUSE, J.; GALLARDO, J. F. Seasonal changes of bioelements in the litter and their potential return to green leaves in four species of the Argentine subtropical forest. Annals of Botany, London, v. 85, n. 2, p. 181-186, 2000.

PEPPELMAN, G.; KEMP, H.; BALKHOVEN-BAART, T. M. J.; GROOT, J. M. Towards high density plum growing - agronomic and economic performance of plum (Prunus domestica L.) on 'VVA-1' rootstock. Acta Horticulturae, Louven, v. 734, n. 1, p. 225-234, 2007.

PROTIC, N.; MARTINOVIC, L.; MILICIC, B.; STEVANOVIC, D.; MOJASEVIC, M. The status of soil surveys in Serbia and Montenegro. In: JONES, R.; HOUŠKOVA, B.; BULLOCK, P.; MONTANARELLA, L. (Ed.). Soil resources of Europe. The European Soil Bureau, Luxemburg: Ispra, 2003. p. 297-315.

RAINS, D. W.; EPSTEIN, E. Transport of sodium in plant tissue. Science, Washington, v. 148, n. 3677, p. 1611-1611, 1965.

RATO, A. E.; AGUlHeiro, A. C.; BARroso, J. M.; RIQUELME, F. Soil and rootstock influence on fruit quality of plums (Prunus domestica L.). Scientia Horticulturae, Amsterdam, v. 118, n. 3, p. 218-222, 2008.

SANZ, M.; MONTAÑÉS, L. Flower analysis as a new approach to diagnosing the nutritional status of the peach tree. Journal of Plant Nutrition, Philadelphia, v. 18, n. 8, p. $1667-1675,1995$.

SINGH, M.; SHARMA J. K. Effect of rootstock on nutrient status of grafted 'Perlette' grapevines at the nursery stage. Acta Horticulturae, Louven, v. 689, n. 1, p. 217-226, 2005.

SOARES, M. C.; RIBEIRO, É. T.; KUSKOSKI, E. M.; GONZAGA, L. V.; LIMA, A.; FILHO, J. M.; FETT, R. Composition of phenolic acidics content in apple (Malus sp.) pomace. Semina: Ciências Agrárias, Londrina, v. 29, n. 2, p. 339-348, 2008.

SOSNA, S. Growth cropping of four plum cultivars on different rootstocks in South Western Poland. Journal of
Fruit and Ornamental Plant Research, Skierniewice, v. 10, n. 1, p. 95-103, 2002.

SOTIROPOULOS, T. E.; DIMASSI, K. N.; TSIRAKOGLOU, V.; THERIOS, I. N. Responses of two Prunus rootstocks to $\mathrm{KCl}$ induced salinity in vitro. Biologia Plantarum, Dordrecht, v. 50, n. 3, p. 477-480, 2006.

TANASIJEVIC, D.; ANTONOVIC, G.; ALEKSIC, Z.; PAVICEVIC, N.; FILIPOVIC, D.; SPASOJEVIC, M. The pedological cover in the west and north-west of Serbia. Soil Research Institute, Topcider: Belgrade, 1966. p. 101-135.

USDA. Soil Taxonomy - A Basic System of Soil Classification for Making and Interpreting Soil Surveys. $2^{\text {nd }}$ Ed. Conservation Service, Natural Resources, n. 436, p. 1-871, 1999. Available at: <ftp://ftp-fc.scegov.usda. gov/NSSC/Soil_ Taxonomy/tax.pdf $>$. Accessed at: 23 may 2009.

VON UEXKÜLL, R. H.; MUTERT, E. Global extent, development and economic impact of acidic soils. Plant and Soil, The Hague, v. 171, n. 1, p. 1-15, 1995.

WEST, W. D. Water use and sodium chloride uptake by apple trees. Plant and Soil, The Hague, v. 50, n. 1-3, p. 37-49, 1978.

XU, G.; MAGEN, H.; TARCHITZKY, J.; KAFKAFI, $\mathrm{U}$. Adveances in chloride nutrition of plant. Advances in Agronomy, San Diego, v. 68, n. 1, p. 97-115, 2000.

ZARROUK, O.; GOGORCENA, Y.; GÓMEZ-APARISI, J.; BETRÁN, J. A.; MORENO, M. A. Influence of almond $\times$ peach hybrids rootstocks on flower and leaf mineral concentration, yield and vigour of two peach cultivars. Scientia Horticulturae, Amsterdam, v. 106, n. 4, p. 502-514, 2005.

ZISKA, L. H.; DEJONG, T. M.; HOFFMAN, G. F.; MEAD, R. M. Sodium and chloride distribution in saltstressed Prunus salicina, a deciduous tree species. Tree Physiology, Victoria, v. 8, n. 1, p. 47-57, 1991. 
